\title{
ERRATUM
}

\section{Toward a conceptual framework for early brain and behavior development in autism}

J Piven, JT Elison and MJ Zylka

Molecular Psychiatry (2018) 23, 165; doi:10.1038/mp.2017.212; published online 17 October 2017

Correction to: Molecular Psychiatry advance online publication, 25 July 2017; doi:10.1038/mp.2017.131

As the result of a missed stage of production, the authors' corrections to align the reference list and citations were not made properly. A corrected version of the paper is now online. The publisher regrets the error. (i) $(\$$ This work is licensed under a Creative Commons AttributionBY NG ND NonCommercial-NoDerivs 4.0 International License. The images or other third party material in this article are included in the article's Creative Commons license, unless indicated otherwise in the credit line; if the material is not included under the Creative Commons license, users will need to obtain permission from the license holder to reproduce the material. To view a copy of this license, visit http:// creativecommons.org/licenses/by-nc-nd/4.0/

(c) The Author(s) 2018 